\title{
Intrinsic Factor-mediated Absorption of Cobalamin by Guinea Pig Ileal Cells
}

\author{
Cyrus R. Kapadia, Del Serfilippi, Kurt Voloshin, and \\ Robert M. Donaldson, Jr., Veterans Administration Medical Center, \\ West Haven, Connecticut 06516; Yale University School of Medicine, \\ New Haven, Connecticut 06510
}

\begin{abstract}
A B S T R A C T To investigate the fate of intrinsic factor and cobalamin during cobalamin absorption, we incubated enterocytes isolated from guinea pig ileum for periods of up to $30 \mathrm{~min}$ with ${ }^{57} \mathrm{Co}$-labeled cyanocobalamin bound either to human intrinsic factor or to rabbit intrinsic factor biosynthetically labeled with $\left[{ }^{35} \mathrm{~S}\right]$ methionine. When the labeled complex was incubated for 30 min with isolated ileal cells under conditions that block cellular metabolism, virtually all cellular radioactivity could be removed by washing the cell surface with EDTA or acid. In contrast, washing removed only half the radioactivity from cells incubated at $37^{\circ} \mathrm{C}$ in $\mathrm{O}_{2}$. When residual cellular radioactivity was extracted and analyzed by gel filtration, $80-94 \%$ of both the ${ }^{35} \mathrm{~S}$ and ${ }^{57} \mathrm{Co}$ radioactivity eluted in the same fractions as the original complex. The remaining $6-20 \%$ eluted as free $\left[{ }^{57} \mathrm{Co}\right]$ cobalamin or $\left[{ }^{35}\right.$ S]methionine. To examine events occurring after 30 min, we instilled into tied-off ileal loops of intact guinea pigs radiolabeled intrinsic factor-cobalamin complex and extracted nondissociable radioactivity 2$4.5 \mathrm{~h}$ later. The proportion of extracted ${ }^{57} \mathrm{Co}$ eluting as free cobalamin increased to $39-46 \%$, that eluting as intrinsic factor-cobalamin complex declined to 22$45 \%$, and $9-34 \%$ now eluted as a macromolecule that reacted with antitranscobalamin II antibody but not antiintrinsic factor antibody. Extracted ${ }^{35} \mathrm{~S}$ radioactivity eluted in several peaks in addition to the intrinsic factor peak. These findings suggest that $(a)$ after reversible attachment of intrinsic factor-cobalamin complex to its ileal surface receptor, an energy-dependent process prevents removal of the complex from the cell
\end{abstract}

Parts of this research were reported at the Annual Meetings of the American Society for Clinical Investigation in May 1979, and the American Gastroenterological Association in May 1980 and May 1981.

Received for publication 10 November 1981 and in revised form 3 November 1982. surface by EDTA or acid; (b) cobalamin dissociates from intrinsic factor and, as suggested by previous workers, binds to a molecule antigenically similar to transcobalamin II; and (c) intrinsic factor is slowly degraded and forms breakdown products that are detectable in ileal extracts.

\section{INTRODUCTION}

Efficient intestinal absorption of physiologic amounts of cobalamin $(\mathrm{Cbl}){ }^{1}$ previously called vitamin $B_{12}$, requires binding of the vitamin to gastric intrinsic factor (IF) followed by attachment of the IF-Cbl complex to specific receptors present on the surface of ileal absorptive cells (1). Although detailed information is available about these initial events, the subsequent fate of the IF-Cbl complex remains uncertain. Investigations to date have yielded conflicting conclusions. Results of experiments with everted gut sacs $(2,3)$, isolated loops of ileum $(4)$, and intact animals $(5,6)$ have suggested that the entire IF-Cbl complex may enter the absorptive cell, whereas other results with everted sacs (7) and ileal loops (8) have been consistent with release of $\mathrm{Cbl}$ from the $\mathrm{IF}-\mathrm{Cbl}$ complex and retention of IF at the cell surface.

Previous workers have measured ileal uptake of radioactively labeled cyanocobalamin in the presence and absence of IF. Since either EDTA or acidification below pH 5.4 completely dissociates IF-Cbl complex from its receptor on isolated ileal brush borders or microvillus membranes (MVM) (9), surface attachment of labeled $\mathrm{Cbl}$ has been distinguished from cellular absorption by measuring radioactivity before and

\footnotetext{
${ }^{1}$ Abbreviations used in this paper: Cbl, cobalamin; $\left[{ }^{57} \mathrm{Co}\right] \mathrm{Cbl},{ }^{57} \mathrm{Co}-$ labeled cyanocobalamin; CCCP, carbonylcyanide $m$-chlorophenyl hydrazone; IF, intrinsic factor; KRB, Krebs-Ringer bicarbonate; MVM, microvillus membranes; TCII, transcobalamin II.
} 
after washing ileal mucosa with EDTA or an acidified buffer. In one recent study (8), an immunocytochemical technique was used to localize IF during $\mathrm{Cbl} \mathrm{ab-}$ sorption.

To investigate events occurring after attachment of IF-Cbl complex to the ileal surface, we have used isolated guinea pig enterocytes as well as tied-off loops of guinea pig ileum. In addition to examining uptake of ${ }^{57} \mathrm{Co}$-labeled cyanocobalamin $\left({ }^{57} \mathrm{Co} \mathrm{Cbl}\right)$, as has been described in previous investigations, we also measured cellular uptake of a purified IF preparation biosynthetically labeled with ${ }^{35}$ S $]$ methionine, in an effort to trace both IF and Cbl during absorption of the vitamin.

\section{METHODS}

Human IF-Cbl complex. Gastric juice obtained with pentagastrin stimulation during routine gastric secretory studies served as the source of human IF. After treatment to inactivate pepsin (10), the gastric juice was centrifuged at $4^{\circ} \mathrm{C}$ pooled, and stored in small aliquots at $-20^{\circ} \mathrm{C}$. This pool of gastric juice bound $105 \mathrm{ng}$ of $\left[{ }^{57} \mathrm{Co}\right] \mathrm{Cbl} / \mathrm{ml}$ as determined by a charcoal-binding assay (11). Greater than $90 \%$ of the binding activity was blocked by anti-IF antibody obtained from a pernicious anemia patient whose serum contained a high titer of both blocking (type I) and binding (type II) antibody activity. Human IF-Cbl complex was prepared by adding an excess of $\left[{ }^{57} \mathrm{Co}\right] \mathrm{Cbl}$ (sp act $15 \mu \mathrm{Ci} / \mu \mathrm{g}$ or $220 \mu \mathrm{Ci}$ ) $\mu \mathrm{g}$, Amersham Corp., Arlington Heights, IL) to an aliquot of gastric juice and removing free $\mathrm{Cbl}$ with hemoglobincoated charcoal as previously described (11).

Rabbit IF biosynthetically labeled with ${ }^{35} S$. Explants of rabbit oxyntic mucosa were maintained in organ culture as described previously (12) except for modifications in the culture medium. Three explants, $\sim 3 \mathrm{~mm}$ each in diameter, were cultured over $1 \mathrm{ml}$ of medium. The culture medium consisted of Cbl-free and methionine-free Trowell's T8 (80\%), Cbl-free and methionine-free NCTC-135 (10\%) and dialyzed fetal calf serum (10\%), all purchased from the Gibco Laboratories, Grand Island Biological Co., Grand Island, NY. Each milliliter of medium also contained $100-200 \mu \mathrm{Ci}$ of $\left[{ }^{35}\right.$ S $]$ methionine (500-1,000 Ci/mmol, New England $\mathrm{Nu}-$ clear, Boston, MA), $100 \mathrm{U}$ of penicillin and $100 \mu \mathrm{g}$ of streptomycin. After $24 \mathrm{~h}$ of incubation at $37^{\circ} \mathrm{C}$ in an atmosphere of 95\% $\mathrm{O}_{2}-5 \% \mathrm{CO}_{2}, 50-72$ mucosal explants were pooled and homogenized with an all glass homogenizer (Kontes Co., Vineland, $\mathrm{NJ}$ ), in $5 \mathrm{ml}$ of $0.1 \mathrm{M}$ phosphate buffer, $\mathrm{pH} 7.4$ containing $0.3 \%$ sodium desoxycholate. The homogenate was centrifuged at $15,000 \mathrm{~g}$ for $10 \mathrm{~min}$ at $4^{\circ} \mathrm{C}$ and the supernatant was filtered through Sephadex G-25 (Pharmacia Fine Chemicals, Piscataway, NJ) to remove residual $\left[{ }^{35}\right.$ S]methionine. Incubation media were pooled and either exhaustively dialyzed for $72 \mathrm{~h}$ against $0.1 \mathrm{M}$ phosphate buffer, $\mathrm{pH}$ 7.4 or filtered through Sephadex G-25 to remove free $\left[{ }^{35}\right.$ S $]$ methionine.

IF was then isolated from the combined tissue extract and culture medium by affinity chromatography as described by Allen and Majerus (13) except that the size and $\mathrm{Cbl}$ content of the Cbl-Sepharose columns were greatly reduced to permit adequate recoveries of purified IF from the minute quantities present in the cultured explants and media (14). Five such isolations yielded ${ }^{35} \mathrm{~S}$-labeled preparations containing $16-73 \mathrm{pmol}$ of IF with a $20,000-79,000 \mathrm{cpm} / \mathrm{pmol}$ sp act Anti-IF antibody blocked $>98 \%$ of the Cbl-binding activity of all ${ }^{35} \mathrm{~S}$-labeled preparations. When saturated with unlabeled cyanocobalamin and fractionated on Sephadex G150 , the ${ }^{35} \mathrm{~S}$-labeled eluted in a single peak identical to that obtained with human IF- $\left[{ }^{57} \mathrm{Co} \mathrm{Cbl}\right.$ complex. This peak was shifted completely to the void volume when treated with anti-IF antibody (Fig. 6). In the four preparations tested, 94-107\% of the ${ }^{35} \mathrm{~S}$ radioactivity was precipitated during double-antibody immunoprecipitation with anti-IF antibody (15) compared with 8-13\% with normal human serum. When subjected to sodium dodecyl sulfate polyacrylamide gel electrophoresis, the purified IF preparation yielded a single peak of ${ }^{35} \mathrm{~S}$ radioactivity with an apparent molecular mass of $53,000 \mathrm{D}$. The amount of ${ }^{35} \mathrm{~S}$-labeled IF bound to $\left[{ }^{57} \mathrm{Co}\right] \mathrm{Cbl}$ taken up by ileal enterocytes was 17 -fold greater than that taken up by jejunal enterocytes.

In vitro studies. Nonfasted Hartley strain male guinea pigs weighing between 250 and $400 \mathrm{~g}$ were used. Enterocytes were isolated from the proximal one-third ("jejunum") or distal third ("ileum") of the intestines as described by Weiser (16).

Aliquots of isolated enterocytes containing 1-4 mg protein (17) were incubated in $5 \mathrm{ml}$ of Cbl-free NCTC-135 supplemented with $1.5 \%$ bovine serum albumin and containing either free $\left[{ }^{57} \mathrm{Co}\right] \mathrm{Cbl}$, IF-bound $\left[{ }^{57} \mathrm{Co}\right] \mathrm{Cbl}$, or $\left[{ }^{57} \mathrm{Co}\right] \mathrm{Cbl}$ bound to transcobalamin II (TCII) isolated from guinea pig plasma (18). In some experiments, $0.2 \mathrm{mM}$ carbonylcyanide $m$-chlorophenylhydrazone (CCCP) was added to the incubation medium. Incubations were carried out for 1-30 min at $\mathrm{pH}$ 7.4 in $50-\mathrm{ml}$ plastic flasks gassed with $95 \% \mathrm{O}_{2}-5 \% \mathrm{CO}_{2}$. Uptake of radioactivity was terminated by addition of $8 \mathrm{ml}$ of ice-cold Krebs-Ringer bicarbonate buffer (KRB) followed by centrifugation at $1,000 \mathrm{~g}$ for $5 \mathrm{~min}$ at $4^{\circ} \mathrm{C}$. The cellular pellet was then washed twice in $8 \mathrm{ml}$ of $\mathrm{KRB}$ and radioactivity was extracted and analyzed as described below.

In three separate experiments, MVM were prepared (19) from isolated enterocytes incubated with IF- $\left[{ }^{57} \mathrm{Co}\right] \mathrm{Cbl}$. We then measured the protein content (17), sucrase activity (20), and $\left.{ }^{57} \mathrm{Co}\right] \mathrm{Cbl}$ radioactivity of these isolated MVM.

The viability of isolated enterocytes was assessed by their ability to exclude trypan blue $(0.5 \%$ in phosphate-buffered saline (PBS), pH 7.2) and by their capacity to incorporate $\left[1-{ }^{14} \mathrm{C}\right]$ leucine into trichloroacetic acid-precipitable protein (12).

In vivo studies. To investigate IF-mediated uptake of $\mathrm{Cbl}$ by ileal mucosa for periods longer than $30 \mathrm{~min}$, we incubated radiolabeled IF-Cbl complex in tied-off loops comprising the distal third (ileum) of guinea pig intestine. Loops were constructed between ligatures of 3-O silk in animals anesthetized by intramuscular injection of Innovar-Vet (Pitman-Moore, Washington Crossing, NJ). Either human IF bound to $1-6.7$ pmol of $\left[{ }^{57} \mathrm{Co}\right] \mathrm{Cbl}$ or purified rabbit ${ }^{35} \mathrm{~S}$-labeled IF bound to 2.4-32 pmol of unlabeled $\mathrm{Cbl}$ were diluted in 6-10 ml of Hanks' balanced salt solution and injected through the wall of the loop with a 30 -gauge needle. The abdominal incision was sutured and the animal allowed to recover. After $30 \mathrm{~min}, 2 \mathrm{~h}$ or $4.5 \mathrm{~h}$, animals were killed, ileal loops excised, and contents removed. Enterocytes were then isolated from these loops as described above.

Extraction and analysis of cellular radioactivity. To remove IF-Cbl complex attached to cell surface receptors, we washed isolated ileal cells with $2.5 \mathrm{mM}$ EDTA in PBS, pH 6.3 (EDTA buffer) or $50 \mathrm{mM}$ acetate buffer, $\mathrm{pH} 0.5$ (acid buffer). Cells were vortexed in $10 \mathrm{ml}$ of buffer, centrifuged, resuspended in the same buffer, incubated at $37^{\circ} \mathrm{C}$ for 15 min with constant agitation, and recentrifuged. To extract residual radioactivity from washed cells, we used repeated 
freezing and thawing followed by sonication with a Kontes microultrasonic cell disrupter (Kontes Co.). The lysate was then centrifuged at $90,000 \mathrm{~g}$ for $45 \mathrm{~min}$ at $4^{\circ} \mathrm{C}$ and the supernatant containing the extracted radioactivity was collected. Two of these extractions were carried out in the continuous presence of three tissue protease inhibitors: $0.5 \mathrm{mM}$ phenylmethylsulfonylfluoride (Sigma Chemical Co., St. Louis, MO), $0.1 \mathrm{mg} / \mathrm{ml}$ soybean trypsin inhibitor (Sigma Chemical Co.), and 1,000 U/ml Trasylol (FBA Pharmaceuticals, New York). In 10 such experiments, $41-75 \%$ of the radioactivity in the lysate was recovered in the supernatant.

The extracted radioactivity in each experiment was divided into either two or three aliquots. The first aliquot was directly subjected to gel filtration on a Sephadex G-150 (Pharmacia Fine Chemicals) column with dimensions of 75 $\times 1.6 \mathrm{~cm}$ (i.d.). $2 \mathrm{ml}$-fractions were eluted with phosphate buffer pH 7.4 containing $2 \mathrm{mM}$ EDTA.

The second aliquot of extracted radioactivity was treated with anti-IF antibody in a quantity sufficient to bind 20 times the amount of IF-Cbl complex present. In two experiments, a third aliquot of extracted radioactivity was treated with both anti-IF antibody and rabbit anti-human TCII antibody (21) before gel filtration.

${ }^{57}$ Co radioactivity was determined using a gamma spectrometer, model 5230, Packard Instrument Co., Inc., Downers Grove, IL. Samples containing ${ }^{35} \mathrm{~S}$ were prepared with Atomlight fluor for radioactivity measurements in a Beckman LS 7000 liquid scintillation system, Beckman Instruments, Inc., Fullerton, CA. Appropriate corrections were made for the contribution of ${ }^{57} \mathrm{Co}$ radioactivity to ${ }^{35} \mathrm{~S}$ measurements.

\section{RESULTS}

In vitro studies. During in vitro incubations, 88$93 \%$ of isolated guinea pig enterocytes excluded trypan blue when incubated for up to $60 \mathrm{~min}$ in oxygenated nutrient medium. We also assessed viability by determining rates of incorporation of $\left[1-{ }^{14} \mathrm{C}\right]$ leucine into tissue protein. Leucine incorporation increased in a linear fashion during the first $30 \mathrm{~min}$ of incubation but then declined. We therefore examined uptake of $\mathrm{Cbl}$ by isolated enterocytes for no longer than $30 \mathrm{~min}$.

When cells from ileum or jejunum were incubated with $\left.{ }^{57} \mathrm{Co}\right] \mathrm{Cbl}$, IF enhanced by 33 -fold the uptake of $\left[{ }^{57} \mathrm{Co}\right] \mathrm{Cbl}$ by ileal cells but had no effect on $\mathrm{Cbl}$ uptake by jejunal cells. Addition of type II anti-IF antibody completely prevented IF-mediated Cbl uptake by ileal cells. In contrast to IF, TCII did not at all increase $\left[{ }^{57} \mathrm{Co}\right] \mathrm{Cbl}$ uptake by ileal enterocytes.

In 24 experiments, IF- $\left.-{ }^{57} \mathrm{Co}\right] \mathrm{Cbl}$ was incubated with ileal cells for $30 \mathrm{~min}$ at $37^{\circ} \mathrm{C}$ in the presence of oxygen. Under these conditions, $47 \pm 6 \%$ (SD) of the radioactivity taken up could be dissociated from the cells by $2.5 \mathrm{mM}$ EDTA whereas $53 \pm 6 \%$ (SD) was considered to be "internalized" in that it could not be removed from the cell surface. Table I shows, however, that when cells were incubated at either $4^{\circ}$ or at $37^{\circ} \mathrm{C}$ in the presence of the uncoupler of oxidative phosphorylation CCCP, total Cbl uptake was reduced by ap-
TABLE I

Uptake of Human IF-bound $\left[{ }^{57} \mathrm{CojCbl}\right.$ by Ileal Cells

\begin{tabular}{lccc}
\hline \multicolumn{1}{c}{ Incubation conditions } & $\begin{array}{c}\text { Surface } \\
\text { attachment }\end{array}$ & $\begin{array}{c}\text { Internalized } \\
\text { Cbl }\end{array}$ & $\begin{array}{c}\text { Total } \\
\text { uptake }\end{array}$ \\
\hline & & fmol $\mathrm{Cb} / \mathrm{mg}$ cell protein \\
$37^{\circ} \mathrm{C}$ & $32 \pm 10$ & $30 \pm 15$ & $62 \pm 22$ \\
$37^{\circ} \mathrm{C}, \mathrm{CCCP}^{\circ}$ added & $21 \pm 4$ & $3 \pm 2$ & $24 \pm 4$ \\
$4^{\circ} \mathrm{C}$ & $27 \pm 10$ & $2 \pm 1$ & $29 \pm 9$ \\
\hline
\end{tabular}

Cells were incubated for $30 \mathrm{~min}$ with human IF-bound $\left[{ }^{57} \mathrm{Co}\right] \mathrm{Cb}$ $(300 \mathrm{pM}) .{ }^{57} \mathrm{Co}$ uptake was measured after washing with PBS (total uptake) or EDTA buffer. (Surface attachment $=\mathrm{Cb}$ removed by EDTA wash; internalized $\mathrm{Cbl}=\mathrm{Cbl}$ remaining after EDTA wash). Mean results $( \pm \mathrm{SD})$ obtained in four animals.

- CCCP: $0.2 \mathrm{mM}$.

proximately one-half, virtually all of the $\mathrm{Cbl}$ taken up could be dissociated from the cell surface by EDTA, and very little radioactivity had been internalized (Table I). Identical results were obtained in four experiments in which cells were washed with an acid buffer instead of EDTA.

Table II summarizes results obtained when isolated ileal enterocytes were incubated with $\left[{ }^{57} \mathrm{Co}\right] \mathrm{Cbl}$ bound to ${ }^{35} \mathrm{~S}$-labeled rabbit IF. After incubation for $30 \mathrm{~min}$ at $37^{\circ} \mathrm{C}$ in the presence of oxygen, $42 \%$ of the ${ }^{57} \mathrm{Co}$ radioactivity and $44 \%$ of the ${ }^{35} \mathrm{~S}$ radioactivity had been internalized and could not be washed from the cell surface by EDTA. When cells were incubated in the presence of CCCP, however, neither the ${ }^{57} \mathrm{Co}$ radioactivity nor the ${ }^{35} \mathrm{~S}$ radioactivity was internalized to any substantial extent.

We also prepared MVM from isolated ileal enterocytes after they had been incubated for $30 \mathrm{~min}$ at $37^{\circ} \mathrm{C}$ with IF-bound $\left[{ }^{57} \mathrm{Co}\right] \mathrm{Cbl}$ and then washed with either PBS or EDTA. Preparation of MVM from isolated en-

TABLE II

Uptake of Rabbit ${ }^{35}$ S IF-bound $\left[{ }^{57} \mathrm{CojCbl}\right.$ by Ileal Cells

\begin{tabular}{llccc}
\hline \multicolumn{1}{c}{ Incubation conditions } & Isotope & $\begin{array}{c}\text { Surface } \\
\text { attachment }\end{array}$ & $\begin{array}{c}\text { Internalized } \\
\text { Cb }\end{array}$ & $\begin{array}{c}\text { Total } \\
\text { uptake }\end{array}$ \\
\hline \multirow{3}{*}{$37^{\circ} \mathrm{C}$} & & \multicolumn{2}{c}{ fmol of $\mathrm{Cb}$ or IF/mg protetn } \\
& & & & \\
$37^{\circ} \mathrm{C}, \mathrm{CCCP}$ added & ${ }^{57} \mathrm{Co}$ & $19 \pm 5$ & $14 \pm 2$ & $33 \pm 7$ \\
& ${ }^{35} \mathrm{~S}$ & $15 \pm 9$ & $12 \pm 5$ & $27 \pm 12$ \\
& ${ }^{57} \mathrm{Co}$ & $18 \pm 6$ & $1 \pm 0.2$ & $19 \pm 5$ \\
& ${ }^{35} \mathrm{~S}$ & $14 \pm 4$ & $1 \pm 0.2$ & $15 \pm 4$ \\
\hline
\end{tabular}

Cells were incubated for $30 \mathrm{~min}$ with purified rabbit ${ }^{35} \mathrm{~S}$ IF-bound $\left[{ }^{57} \mathrm{Co}\right] \mathrm{Cbl}(300 \mathrm{pM})$. Both ${ }^{57} \mathrm{Co}$ and ${ }^{35} \mathrm{~S}$ radioactivity was measured after washing with PBS (total uptake) or EDTA buffer (surface attachment $={ }^{57} \mathrm{Co}$ or ${ }^{35} \mathrm{~S}$ removed by EDTA; internalized $\mathrm{Cbl}$ $={ }^{57} \mathrm{Co}$ or ${ }^{35} \mathrm{~S}$ remaining after washing with EDTA). Mean results $( \pm \mathrm{SD})$ obtained in three animals. 
terocytes resulted in a 16-fold increase in sucrase activity. When ileal cells had been washed with PBS before MVM were prepared, the $\mathrm{Cbl}$ content of MVM in two experiments ( 155 and $88 \mathrm{fmol} \mathrm{Cbl} /$ sucrase unit) was substantially greater than when the cells had been washed with EDTA ( 15 and $10 \mathrm{fmol} \mathrm{Cbl} /$ sucrase unit). On the other hand, the sucrase content of MVM prepared from cells washed with EDTA (0.70 sucrase units/mg MVM protein) was not reduced compared with that of cells washed with PBS (0.55 sucrase units/ mg MVM protein). In these two experiments, the $\mathrm{Cbl}$, which was still associated with MVM after ileal cells had been washed with EDTA, amounted to 0.5-0.7 $\mathrm{fmol} \mathrm{Cbl} / \mathrm{mg}$ ileal cell protein. The internalized $\mathrm{Cbl}$ present in the ileal cells after the EDTA wash was 19$35 \mathrm{fmol} / \mathrm{mg}$ cell protein.

In an additional experiment, ileal cells were incubated with IF-bound $\left[{ }^{57} \mathrm{Co}\right] \mathrm{Cbl}$ for $10 \mathrm{~min}$ at $37^{\circ} \mathrm{C}$, centrifuged, and resuspended in nonradioactive medium. Half the cells were then incubated at $4^{\circ} \mathrm{C}$ and the other half at $37^{\circ} \mathrm{C}$ for an additional $20 \mathrm{~min}$, after which time MVM were prepared. Total sucrase activity per milligram MVM protein were similar in MVM prepared from the two groups of cells. However, MVM isolated from cells reincubated at $4^{\circ} \mathrm{C}$ contained 159 fmol Cbl/sucrase unit compared with only $74 \mathrm{fmol}$ $\mathrm{Cbl} /$ sucrase unit in MVM from cells reincubated at $37^{\circ} \mathrm{C}$.

Fig. 1 illustrates the time course of IF-Cbl uptake by ileal enterocytes during $30 \mathrm{~min}$ of incubation with $\left[{ }^{57} \mathrm{Co}\right] \mathrm{Cbl}$ bound to human IF. Surface attachment of $\mathrm{Cbl}$ increased rapidly with time and was maximal at
5 min. In contrast, internalized $\mathrm{Cbl}$ was detectable at $5 \mathrm{~min}$ and accumulated thereafter in a linear fashion.

To determine whether continuous protein synthesis was essential for surface attachment or internalization of $\mathrm{Cbl}$, we incubated ileal cells with IF-bound $\left[{ }^{57} \mathrm{Co}\right] \mathrm{Cbl}$ for $30 \mathrm{~min}$ in the presence or absence of cycloheximide $(0.5 \mathrm{mg} / \mathrm{ml})$, a concentration five times that which completely blocked incorporation of leucine into protein. In three such experiments, cycloheximide had no effect on total $\mathrm{Cbl}$ uptake, surface attachment or internalization.

In four separate experiments, internalized radioactivity was extracted from isolated ileal cells incubated with IF- $\left.-{ }^{57} \mathrm{Co}\right] \mathrm{Cbl}$ complex for $30 \mathrm{~min}$. When applied to a Sephadex G-150 column, 93-99\% of the extracted radioactivity was recovered in virtually identical elution patterns. Of the recovered radioactivity, 80-94\% eluted symmetrically in a single major peak (henceforth termed "IF peak"), identical to the peak obtained when human IF bound to $\left[{ }^{57} \mathrm{Co}\right] \mathrm{Cbl}$ had been applied separately to the same column. The remaining 6-20\% eluted in a minor peak, identical to the peak obtained when free $\left[{ }^{57} \mathrm{Co}\right] \mathrm{Cbl}$ was separately applied. When aliquots of the extracted radioactivity in two experiments were subjected to gel filtration after reaction with anti-IF antibody, the major peak of radioactivity shifted completely to the void volume.

To determine whether the radioactivity that eluted as free $\left[{ }^{57} \mathrm{Co}\right] \mathrm{Cbl}$ had been released from IF during absorption or during the extraction procedure, we added human IF-bound $\left[{ }^{57} \mathrm{Co}\right] \mathrm{Cbl}$ to isolated ileal cells at $4^{\circ} \mathrm{C}$ and immediately extracted the radioactivity.
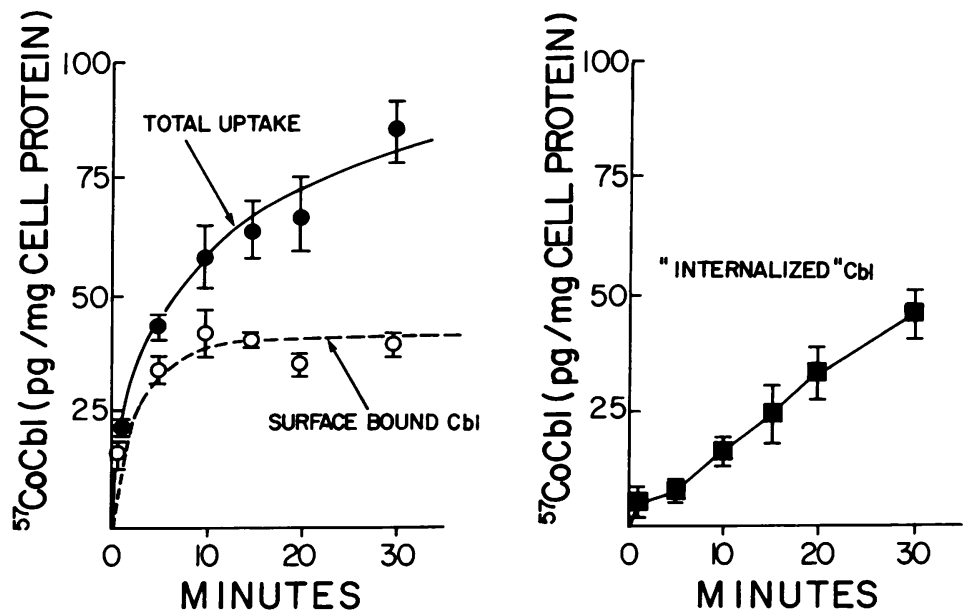

Figure 1 Time course of $\mathrm{Cbl}$ uptake by isolated ileal cells. Cells were incubated with $300 \mathrm{pM}$ IF-bound $\left[{ }^{57} \mathrm{Co}\right] \mathrm{Cbl}$ at $37^{\circ} \mathrm{C}$. Total uptake of $\mathrm{Cbl}$ (closed circles, left panel) was determined in an aliquot of cells washed with PBS. A second aliquot was washed with EDTA for measurement of internalized $\mathrm{Cbl}$ (right panel). The calculated difference between total and internalized $\mathrm{Cbl}$ gave surface bound $\mathrm{Cbl}$ (open circles, left panel). Circles and bars represent mean results $\pm S D$ for four experiments. 
In this control experiment, $95 \%$ of the extracted radioactivity was recovered as intact $\left[\mathrm{F}-\left[{ }^{57} \mathrm{Co}\right] \mathrm{Cbl}\right.$ complex, whereas $5 \%$ eluted as free $\mathrm{Cbl}$. By contrast, when human IF-bound $\left[{ }^{57} \mathrm{Co}\right] \mathrm{Cbl}$ was directly applied to Sephadex without being subjected to the extraction procedure, $100 \%$ eluted as IF-Cbl complex. Thus, a small proportion of the radioactivity that elutes in the minor (free $\mathrm{Cbl}$ ) peak during gel filtration results from degradation of the IF-Cbl complex due to the extraction process itself or to exchange between endogenous and labeled $\mathrm{Cbl}$. When ileal enterocytes were incubated for $30 \mathrm{~min}$ with ${ }^{35} \mathrm{~S}$-labeled IF bound to $\left[{ }^{57} \mathrm{Co}\right] \mathrm{Cbl}$, the internalized radioactivity consisted of both ${ }^{35} \mathrm{~S}$ and ${ }^{57} \mathrm{Co}$. Fig. 2 shows that in the absence of anti-IF antibody, all the extracted ${ }^{35} \mathrm{~S}$ radioactivity eluted in the IF peak. Of the extracted ${ }^{57} \mathrm{Co}$ radioactivity, $92 \%$ eluted in this same peak. The ratio of ${ }^{35} \mathrm{~S}$ to ${ }^{57} \mathrm{Co}$ radioactivity in the peak was the same as that in the original incubation medium. Moveover, reaction with anti-IF antibody shifted all of the ${ }^{35} \mathrm{~S}$ and ${ }^{57} \mathrm{Co}$ radioactivity to the void volume.

In vivo studies. To examine ileal mucosal uptake of IF-Cbl for periods longer than $\mathbf{3 0}$ min, we instilled human IF-bound $\left[{ }^{57} \mathrm{Co}\right] \mathrm{Cbl}$ into tied-off ileal loops of guinea pigs and at various intervals thereafter, isolated enterocytes from these loops. In all experiments, Cbl was absorbed from ileal loops as indicated by readily detectable ${ }^{57} \mathrm{Co}$ radioactivity in plasma and increasing amounts of radioactivity in the liver, spleen, and kidneys.

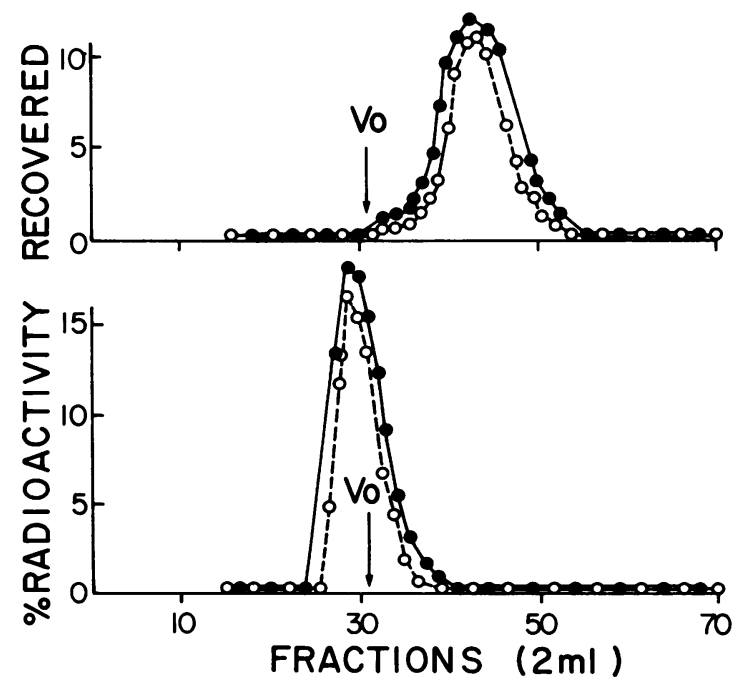

FigURE 2 Gel filtration of internalized radioactivity. Ileal cells were incubated with $\left[{ }^{57} \mathrm{Co}\right] \mathrm{Cbl}(\bullet)$ bound to ${ }^{35} \mathrm{~S}$-labeled rabbit IF (O) for $30 \mathrm{~min}$ and then washed with EDTA. The upper panel shows the elution profile of extracted residual activity. The lower panel shows the elution pattern after treatment with anti-IF antibody. Vo marks the end of dextran blue elution.
Afer $30 \mathrm{~min}$ of in vivo incubation, the results of gel filtration (Fig. 3A) were the same as those obtained after $30 \mathrm{~min}$ of in vitro incubation. Of the ${ }^{57} \mathrm{Co}$ recovered, $75 \%$ eluted in the IF peak and was completely shifted to the void volume with anti-IF antibody. The remaining $25 \%$ eluted as free $\left[{ }^{57} \mathrm{Co}\right] \mathrm{Cbl}$. After $2 \mathrm{~h}$ of incubation, $46 \%$ of the radioactivity eluted as free $\left[{ }^{57} \mathrm{Co}\right] \mathrm{Cbl}$ while the remainder eluted in the IF peak (Fig. 3B). However, anti-IF antibody now shifted only $67 \%$ of the IF peak in one experiment and $84 \%$ in the other to the void volume, suggesting that $16-33 \%$ of the $\left.{ }^{57} \mathrm{Co}\right] \mathrm{Cbl}$ in this peak was bound to a macromolecule other than IF. After $4.5 \mathrm{~h}$ of in vivo incubation in three animals (Fig. 3C shows results of a representative experiment), $39-41 \%$ of the recovered radioactivity eluted as free $\left[{ }^{57} \mathrm{Co}\right] \mathrm{Cbl}, 55-56 \%$ in the IF peak and $4-5 \%$ in the void volume. The nature of this small peak in the void volume is unclear but was a constant finding at $4.5 \mathrm{~h}$. In four animals, anti-IF antibody now shifted only $39-54 \%$ of the IF peak to the void volume so that $46-61 \%$ of the $\left.{ }^{57} \mathrm{Co}\right] \mathrm{Cbl}$ in this peak was now bound to a macromolecule other than IF. Fig. 4 shows that when this IF peak was treated with an excess of anti-TCII antibody and reapplied to the column, 59\% of the radioactivity now shifted to the void volume and the remaining $41 \%$ eluted with the IF peak. In two additional experiments, the extracted cellular radioactivity was treated with both anti-IF antibody and anti-TCII antibody before gel filtration. Now $80-87 \%$ of the IF peak shifted to the void volume (Fig. 5).

In three separate experiments, we instilled purified rabbit ${ }^{35} \mathrm{~S}$-labeled IF bound to unlabeled $\mathrm{Cbl}$ into tiedoff ileal loops, isolated enterocytes from these loops 4.5 $\mathrm{h}$ later, and extracted the internalized ${ }^{35} \mathrm{~S}$ radioactivity. Fig. 6 shows that the original complex yielded a single peak of radioactivity, which shifted entirely to the void volume when treated with anti-IF antibody. In contrast, the ${ }^{35}$ S extracted from cells yielded several peaks of radioactivity (Fig. 6). One peak of ${ }^{35}$ S eluted in the region of purified ${ }^{35} \mathrm{~S}$-IF. One peak eluted before and several peaks eluted after the IF peak. When the extracted radioactivity was reacted with anti-IF antibody, all of the ${ }^{35} \mathrm{~S}$ in the IF peak and $85 \%$ of that in the smaller peaks shifted to the void volume. To be certain that these peaks of ${ }^{35} \mathrm{~S}$ radioactivity were not produced by tissue proteases activated during the extraction procedure, we added tissue protease inhibitors throughout one extraction and obtained identical results.

\section{DISCUSSION}

Guinea pig enterocytes appeared to be suitable for examination of IF-mediated absorption of Cbl since IF markedly enhanced Cbl uptake by cells isolated 


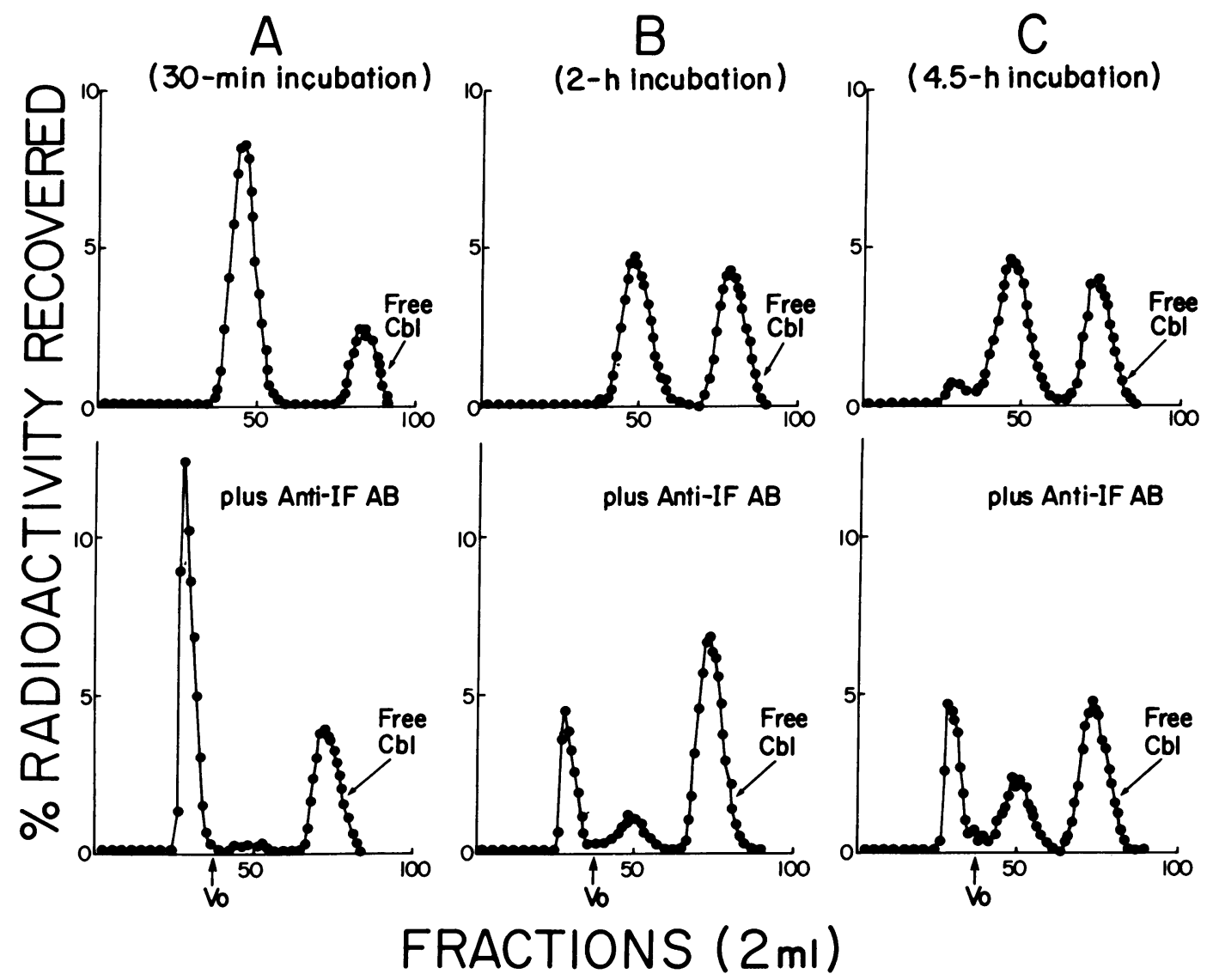

FIGURE 3 Gel filtration of internalized radioactivity. IF-bound $\left.{ }^{57} \mathrm{Co}\right] \mathrm{Cbl}$ was instilled into distal ileal loops. After $30 \mathrm{~min}(\mathrm{~A}), 2 \mathrm{~h}(\mathrm{~B})$, or $4.5 \mathrm{~h}(\mathrm{C})$, mucosal cells were isolated and washed with EDTA. Residual radioactivity was extracted and subjected to gel filtration before (upper panels) and after (lower panels) treatment with anti-IF antibody. Vo marks the end of blue dextran elution.

from the ileum but not the jejunum, since this IF-mediated uptake was completely blocked by anti-IF antibody, and since IF action was specific in that another Cbl-binding protein, TCII, did not promote Cbl uptake. Because of the limited viability of isolated enterocytes, however, these cells could be used for only $30 \mathrm{~min}$. Moreover, isolated enterocytes may be sufficiently damaged in their preparation that observed phenomena cannot be assumed to be physiological. Therefore, it was necessary to examine IF-mediated absorption of $\mathrm{Cbl}$ not only by isolated ileal cells but also by ileal mucosa of intact guinea pigs.

Using various experimental methods, previous investigators have shown that ileal uptake of IF-bound $\mathrm{Cbl}$ requires extracellular calcium and a $\mathrm{pH}>5.4(9$, $10,22-24)$. Reduction of $\mathrm{pH}$ or chelation of calcium ions not only prevents attachment of IF-Cbl complex to ileal surface receptors, but also completely dissociates IF-Cbl already attached to isolated MVM (9).
Therefore, by incubating isolated ileal cells with radiolabeled IF-bound $\mathrm{Cbl}$ and by washing these cells with EDTA or a pH 5.0 buffer, we were able to distinguish radioactivity attached to the cell surface from that which had been internalized. The washing procedure used was particularly vigorous to assure complete removal of surface attached radioactivity.

When isolated ileal cells were incubated for $30 \mathrm{~min}$ under conditions that blocked cellular metabolism, virtually all the labeled $\mathrm{Cbl}$ and IF taken up by ileal cells could be dissociated from the cell surface by EDTA or acid. In contrast, incubation at $37^{\circ} \mathrm{C}$ in the presence of oxygen resulted in internalization of approximately half the radioactivity taken up.

To be certain that washing cells with EDTA or acid had not merely stripped MVM from cells with IF-Cbl complex still attached, we isolated MVM from ileal cells previously incubated with IF-bound $\left[{ }^{57} \mathrm{Co}\right] \mathrm{Cbl}$ and then washed with EDTA. These experiments in- 


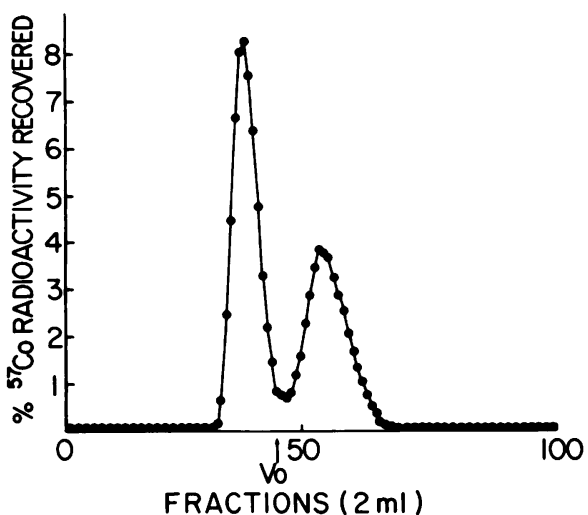

Figure 4 Effect of anti-TCII antibody on gel filtration of internalized radioactivity. The macromolecular IF peak shown in Fig. 3C, upper panel was treated with anti-TCII antibody and subjected to gel filtration. Vo marks the end of dextran blue elutions.

dicated that $\mathrm{Cbl}$, but not sucrase, had been removed from MVM by EDTA. Moreover, the amount of $\mathrm{Cbl}$ remaining on MVM after ileal cells had been washed with EDTA (0.5-0.7 fmol/mg cell protein) was substantially less than the amount of $\mathrm{Cbl}$ internalized (19$35 \mathrm{fmol} / \mathrm{mg}$ cell protein), and could not be dissociated from the cells by vigorous washing with EDTA.

The results of these in vitro studies, thus, clearly document two distinct steps in IF-mediated uptake of $\mathrm{Cbl}$ : an initial, energy-independent attachment of IF$\mathrm{Cbl}$ complex to the ileal cell surface followed by in-

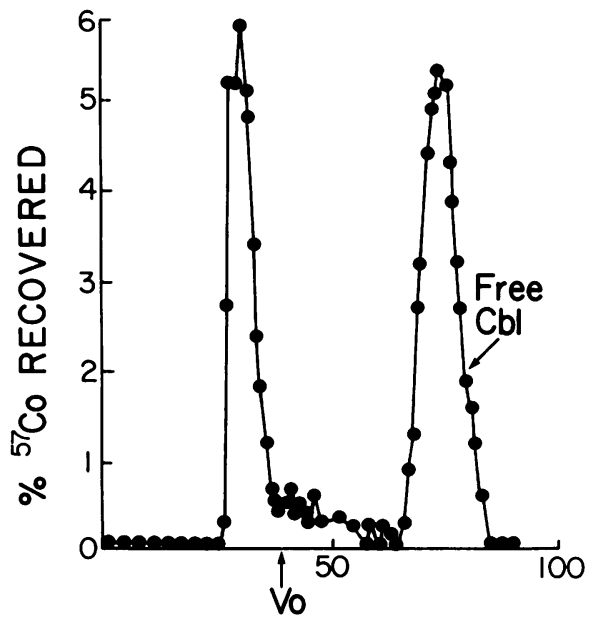

FRACTIONS ( $2 \mathrm{ml})$

FIGURE 5 Effect of anti-IF and anti-TCII antibodies on gel filtration of internalized radioactivity. Residual radioactivity was extracted from ileal mucosa which had been incubated in vivo with IF-bound $\left[{ }^{57} \mathrm{Co}\right] \mathrm{Cbl}$ for $4.5 \mathrm{~h}$. The extract was treated with antibodies against both IF and TCII. Vo marks the end of dextran blue elution.

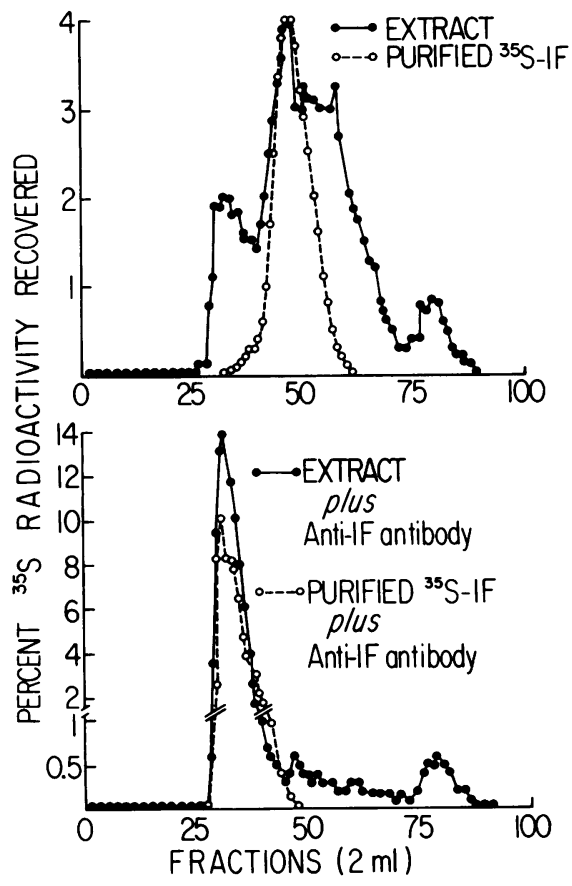

Figure 6 Gel filtration of ${ }^{35} \mathrm{~S}$ internalized radioactivity. Residual radioactivity was extracted from ileal mucosa incubated in vivo with ${ }^{35} \mathrm{~S}$-labeled rabbit IF bound to unlabeled $\mathrm{Cbl}$ for $4.5 \mathrm{~h}$. The closed circles show the elution pattern before (upper panel) and after (lower panel) treatment with anti-IF antibody. The open circles show the elution patterns of the original ${ }^{35} \mathrm{~S}$-labeled IF bound to unlabeled $\mathrm{Cbl}$.

ternalization of $\mathrm{Cbl}$ by a process that requires cellular metabolic energy but not the continuous synthesis of new protein by the cell. Previous workers have used everted gut sacs in attempts to distinguish surface attachment from cellular absorption, and entry of $\mathrm{Cbl}$ into mucosa has been detected within $20 \mathrm{~min}$ (24). Until now, however, it has not been possible to delineate clearly the early time course of these two phases of IF-mediated cellular uptake of $\mathrm{Cbl}$ (Fig. 1). It is likely that suspensions of mucosal cells are more rapidly and uniformly exposed to IF-Cbl complex than are everted sacs or slices of intestine during in vitro incubations. Since internalization of $\mathrm{Cbl}$ can be readily detected within 5 min of exposure of ileal enterocytes to IF-bound $\left[{ }^{57} \mathrm{Co}\right] \mathrm{Cbl}$, the long delay that occurs during IF-mediated transport of Cbl across the ileum (25) may occur after entry of $\mathrm{Cbl}$ into ileal cells.

The results of in vitro incubations also support the concept that IF as well as $\mathrm{Cbl}$ is altered so that it can not be removed from the absorptive cell surface. When ileal cells were incubated with ${ }^{35} \mathrm{~S}$-labeled IF bound to $\left[{ }^{57} \mathrm{Co}\right] \mathrm{Cbl}$, both the ${ }^{35} \mathrm{~S}$ and the ${ }^{57} \mathrm{Co}$ were consistently internalized to the same extent (Table II). Moreover, both the ${ }^{35} \mathrm{~S}$ and ${ }^{57} \mathrm{Co}$ radioactivity extracted from ileal 
cells after washing with EDTA eluted in a single peak of radioactivity identical to that obtained with IFbound $\mathrm{Cbl}$ and that reacted with anti-IF antibody.

When radiolabeled IF-Cbl complex was incubated in ileal loops of intact guinea pigs for $30 \mathrm{~min}$, the results were similar to those obtained with in vitro incubations: nearly all the internalized radioactivity was present as immunoreactive IF-Cbl complex. After 2 and $4.5 \mathrm{~h}$ of such in vivo incubation, however, the proportion of internalized radioactivity present as free Cbl increased markedly. In addition, an increasing amount of $\left[{ }^{57} \mathrm{Co}\right] \mathrm{Cbl}$ was now bound to a macromolecule which reacted with anti-TCII antibody but not with anti-IF antibody.

These observations suggest that internalized $\mathrm{Cbl}$ is slowly released from IF and then binds to a macromolecule antigenically similar to TCII. The binding of $\mathrm{Cbl}$ to a TCII-like molecule within guinea pig ileal mucosa has previously been described by Rothenberg et al. (26) and is consistent with the results of in vivo perfusions of $\mathrm{Cbl}$ in rats (27) as well as indirect observations in man (28). Still unclear is whether the TCII-like molecule is synthesized by the ileal cell or enters that cell from plasma. Results reported by Rothenberg et al. (26) suggest that this binder cannot be detected in ileal cells until $\mathrm{Cbl}$ absorption occurs.

To examine the fate of internalized IF, we incubated ${ }^{35} \mathrm{~S}$-labeled IF bound to $\mathrm{Cbl}$ in guinea pig ileal loops for $4.5 \mathrm{~h}$. When the ${ }^{35} \mathrm{~S}$ radioactivity was extracted from these loops and filtered on Sephadex, it eluted not only as immunoreactive IF, but also as a highmolecular weight peak in the void volume and as several small peaks, some of which reacted with anti-IF antibody. These results suggest that cellular degradation yields fragments of ${ }^{35} \mathrm{~S}$-labeled IF, some of which share antigenic determinants with intact IF (Fig. 6). Some ${ }^{35}$ S-labeled IF may well be completely degraded within the enterocyte, at the cell surface or within the lumen to form free $\left[{ }^{35} \mathrm{~S}\right]$ methionine, which the ileal cell then incorporates into new ${ }^{35} \mathrm{~S}$-labeled protein. Obviously needed are experiments that examine directly the degradation of ${ }^{35} \mathrm{~S}$-labeled IF by homogenates and subcellular fractions of ileal mucosal cells.

From this investigation, it is evident that a substantial proportion of IF-Cbl complex cannot be dissociated from the cell surface after it has been taken up by ileal enterocytes. Our studies, however, do not permit conclusions concerning the cellular location of this internalized IF-Cbl complex. Much of the nondissociable IF-bound $\mathrm{Cbl}$ does appear to be membranebound. Rigorous extraction procedures including sonication were necessary to release the complex from cellular homogenates. When ileal cells were simply homogenized in isotonic medium and centrifuged, the
$100,000 \mathrm{~g}$ supernatant contained $<5 \%$ of the internalized radioactivity. This finding is similar to that previously reported by Marcoullis and Rothenberg (29), who extracted immunoreactive (but biologically inactive) IF from ileal mucosa during IF-mediated Cbl absorption in the dog. These workers found that a substantial proportion of extracted $\left[{ }^{57} \mathrm{Co}\right] \mathrm{Cbl}$ was membrane bound and was solubilized with Triton X-100. Our results suggest that internalized IF-Cbl complex, although membrane bound, does not appear to be bound to MVM since most of the complex disappeared from the MVM fraction of cells that had been extensively washed with EDTA. It should, nevertheless, be emphasized that our results do not provide direct evidence of entry of the IF-Cbl complex into the cell.

Other investigators (2-6) have previously reported findings consistent with such entry but were unable to trace IF directly with a specific label. Using an approach very similar to that used in our in vivo experiments, for example, Rothenberg et al. (4) previously described IF-bound labeled $\mathrm{Cbl}$ associated with the mitochondrial fraction of guinea pig ileal cells. On the other hand, there has been no direct morphologic demonstration of the presence of IF within ileal cells during absorption. In a carefully executed study, Levine et al. (8) instilled IF-bound $\mathrm{Cbl}$ into loops of guinea pig ileum and searched for IF with a sensitive immunocytochemical technique. IF was detected at the surface of ileal enterocytes in pits between adjacent microvilli, but no IF could be identified within absorptive cells. Although the possibility remains that the technique used was not sufficiently sensitive to detect intracellular IF, it is also clear that further investigation are needed to delineate the precise pathways taken by IF and $\mathrm{Cbl}$ during ileal absorption of the vitamin.

\section{ACKNOWLEDGMENTS}

We thank Robert $\mathrm{H}$. Allen for providing anti-human TCII antibody.

This research was supported by the Medical Research Service of the Veterans Administration and by a grant (AM17509) from the National Institutes of Health.

\section{REFERENCES}

1. Donaldson, R. M. 1981. Intrinsic factor and the transport of cobalamin. In Physiology of the Gastrointestinal Tract. L. R. Johnson, editor. Raven Press, New York, 1: 641-658.

2. Boas, A., and T. H. Wilson. 1964. Intestinal absorption of intrinsic factor and $\mathrm{B}_{12}$-intrinsic factor complex. Am. J. Physiol. 207: 27-32.

3. Cooper, B. A. 1964. The uptake of $\mathrm{Co}^{57}$-labeled vitamin $\mathrm{B}_{12}$ by everted sacs of intestine in vitro. Medicine (Baltimore). 43: 689-696.

4. Rothenberg, S. P., H. Weisberg, and A. Ficarra. 1972. 
Evidence for the absorption of immunoreactive intrinsic factor into the intestinal epithelial cell during vitamin $\mathrm{B}_{12}$ absorption. J. Lab. Clin. Med. 79: 587-597.

5. Ukyo, S., and B. A. Cooper. 1965. Intrinsic factor-like activity in extracts of guinea pig intestine. Am. J. Physiol. 208: 9-13.

6. Cooper, B. A. 1968. Complex of intrinsic factor and $B_{12}$ in human ileum during vitamin $\mathrm{B}_{12}$ absorption. Am. J. Physiol. 214: 832-835.

7. Hines, J. D., A. Rosenberg, and J. W. Harris. 1968. Intrinsic factor-mediated radio- $B_{12}$-uptake in sequential incubation studies using everted sacs of guinea pig small intestine: evidence that IF is not absorbed into the intestinal cells. Proc. Soc. Exp. Biol. Med. 129: 653-658.

8. Levine, J. S., P. K. Nakane, and R. H. Allen. 1982. Immunocytochemical localization of intrinsic factor-cobalamin bound to guinea pig ileum in vivo. Gastroenterology. 82: 284-290.

9. MacKenzie, I. L., and R. M. Donaldson, Jr. 1972. Effect of divalent cations and $\mathrm{pH}$ on intrinsic factor-mediated attachment of vitamin $B_{12}$ to intestinal microvillus membranes. J. Clin. Invest. 51: 2465-2471.

10. Cooper, B. A., and W. B. Castle. 1960. Sequential mechanisms in the enhanced absorption of vitamin $B_{12}$ by intrinsic factor in the rat. J. Clin. Invest. 39: 199-214.

11. Gottlieb, C., L. Kam-Seng, L. R. Wasserman, and V. Herbert. 1965. Rapid charcoal assay for intrinsic factor, gastric juice unsaturated $\mathrm{B}_{12}$ binding capacity. Blood. 25: 875-884.

12. Sutton, D. R., and R. M. Donaldson, Jr. 1975. Synthesis and secretion of protein and pepsinogen by rabbit gastric mucosa in organ culture. Gastroenterology. 69: 166-174.

13. Allen, R. M., and P. W. Majerus. 1972. Isolation of vitamin $\mathrm{B}_{12}$-binding proteins using affinity chromatography. 1. J. Biol. Chem. 247: 7695-7701.

14. Serfilippi, D., and R. M. Donaldson. 1979. Biosynthesis of radio-labeled intrinsic factor by isolated gastric mucosa. Gastroenterology. 76: 1241 la. (Abstr.)

15. Taylor, K. B., I. M. Roitt, D. Doniach, K. G. Couchman, and C. Shapland. 1962. Autoimmune phenomena in pernicious anaemia: gastric antibodies. Br. Med. J. 2: 13471352.

16. Weiser, M. M. 1973. Intestinal epithelial cell surface membrane glycoprotein synthesis.-1. An indicator of cellular differentiation. J. Biol. Chem. 248: 2536-2541.
17. Lowry, O. H., N. J. Rosebrough, A. L. Farr, and R. J. Randall. 1951. Protein measurement with the Folin phenol reagent. J. Biol. Chem. 193: 265-275.

18. Bloomfield, F. J., and J. M. Scott. 1972. Identification of a new vitamin $B_{12}$ binder (transcobalamin III) in normal human serum. Br. J. Haematol. 22: 33-42.

19. Will, P. C., and U. Hopfer. 1979. Apparent inhibition of active nonelectrolyte transport by an increased sodium permeability of the plasma membrane. J. Biol. Chem. 254: 3806-3811.

20. Dahlqvist, A. 1968. Assay of intestinal disaccharidases. Anal. Biochem. 22: 99-107.

21. Schneider, R. J., C. S. Mehlman, and R. H. Allen. 1976. The role and fate of rabbit and human transcobalamin II in the plasma transport of vitamin $B_{12}$ in the rabbit. J. Clin. Invest. 57: 27-38.

22. Herbert, V. 1959. Mechanism of intrinsic factor action in everted sacs of rat small intestine. J. Clin. Invest. 38: 102-109.

23. Herbert, V., and W. B. Castle. 1961. Divalent cation and $\mathrm{pH}$ dependence of rat intrinsic factor action in everted sacs and mucosal homogenates of rat small intestine. $J$. Clin. Invest. 40: 1978-1983.

24. Cooper, B. A., W. Paranchych, and L. Lowenstein. 1962. Studies on the absorption by guinea pig intestine of cyanocobalamin incubated with intrinsic factor. J. Clin. Invest. 41: 370-377.

25. Doscherholmen, A., P. S. Hagen, and M. Liu. 1957. A dual mechanism of vitamin $B_{12}$ plasma absorption. $J$. Clin. Invest. 36: 1551-1557.

26. Rothenberg, S. P., J. P. Weiss, and R. Cotter. 1978. Formation of transcobalamin II-vitamin $B_{12}$ complex by guinea pig ileal mucosa in organ culture after in vivo incubation with intrinsic factor-vitamin $\mathrm{B}_{12} . \mathrm{Br}$. J. Haematol. 40: 401-414.

27. Katz, M., and R. O'Brien. 1979. Vitamin $B_{12}$ absorption studied by vascular perfusion of rat intestine. J. Lab. Clin. Med. 94: 817-825.

28. Chanarin, I., M. Muir, A. Hughes, and A. V. Hoffbrand. 1978. Evidence for intestinal origin of transcobalamin II during vitamin $\mathrm{B}_{12}$ absorption. Br. Med. J. 1: 14531455.

29. Marcoullis, G., and S. P. Rothenberg. 1981. Intrinsic factor mediated intestinal absorption of cobalamin in the dog. Am. J. Physiol. 241: G294-G299. 